\title{
Academic Librarians' Changing Perceptions of Faculty Status and Tenure
}

\section{Elise Silva, Quinn Galbraith, and Michael Groesbeck}

\begin{abstract}
This study explores how time and experience affect an academic librarian's perception of tenure. Researchers surveyed 846 librarians at ARL institutions, reporting on institutions that offer both tenure and faculty status for their academic librarians or neither. The survey reported how librarians rated tenure's benefit to patrons, its effect in attracting and retaining quality employees, and tenure as a motivating factor in giving extra effort on the job. Researchers found that tenured librarians rated tenure as more beneficial than librarians without tenure who had more than six years of work experience at their institutions. Furthermore, non-tenure-track librarians with fewer than six years of experience at their institutions rated tenure's effect on library patrons as more beneficial than tenure-track librarians who had not yet achieved tenure. The study implies a selective perception bias on the part of academic librarians that grows with time and warrants further consideration and study.
\end{abstract}

\section{Introduction}

The tension between service and research in an academic library comes to a head over the question of tenure-a hotly debated topic within the realm of research libraries. The "Association of College and Research Libraries Standards for Faculty Status for Academic Librarians" document serves as a grounding point for discussion. ACRL prescribes that academic librarians with faculty status be "covered by a stated tenure policy" and "should be promoted in rank based on their professional proficiency and effectiveness...consistent with stated campus standards." ${ }^{1}$ In addition to promotion and pay equity, tenure is meant to create a culture of respect between faculty outside the library and library faculty, provide the chance for librarians to serve on university committees, and grant librarians the power afforded by academic freedom in their research.

As a service profession, however, there remain questions about tenure's true benefit to academic librarians, to patrons, and to the institutions they serve. Such questions arise in part from uneven institutional support of academic librarians' research (including disparity in research funds and access to sabbaticals when compared with faculty

*Elise Silva is Freshman Programs Librarian, Quinn Galbraith is Sociology and Family Life Librarian, and Michael Groesbeck is a Research Assistant, all in the Harold B. Lee Library at Brigham Young University; e-mail: elise_silva@byu.edu, quinn_galbraith@byu.edu, mdgroesbeck@gmail.com. (C2017 Elise Silva, Quinn Galbraith, and Michael Groesbeck, Attribution-NonCommercial (http://creativecommons. org/licenses/by-nc/4.0/) CC BY-NC. 
outside the library). ${ }^{2}$ Furthermore, the quality of such research has been questioned, given that the terminal degree for an academic librarian is at a master's level and not at a doctoral level. ${ }^{3}$ Finally, the hazy definitions of (and distinctions between) "faculty status" and "tenure" among different organizations make its effect notoriously difficult to systematically study. ${ }^{4}$ Because of this, though the question of tenure and faculty status in libraries has a long history in academic literature, much of that literature has been opinion-based or even anecdotal. ${ }^{5}$ The authors sought to fill a gap in this conversation by surveying academic librarians at different levels in their careers to discern their actual perceptions of faculty status and then compare how these views morph over time in the profession. The present study is important because it uncovers the changing opinions of academic librarians in relation to tenure. It also adds more empirical evidence to conversations about tenure, and how tenure is currently viewed in academic libraries.

To clarify terms, faculty status refers to academic librarians being given similar rights and privileges as teaching faculty; tenure refers to the availability of continuous appointment and permanent employment by an institution. In conjunction with ACRL guidelines, institutions with faculty status should also offer tenure, meaning that tenure is an extension of, and an end goal to, faculty status. For this study, the authors purposefully studied institutions that either offered both faculty status and tenure to their librarians or neither faculty status nor tenure. This was done to standardize the language and preserve the reliability of results insofar as is possible. This also means that, in general, the terms "faculty status" and "tenure" are used interchangeably in the following discussions.

To study academic librarians' perception of tenure, the authors gathered opinions in a few key areas: its benefit to patrons, its ability to attract and retain quality employees, and its motivational strength in giving extra effort in one's job. The authors compared the responses of librarians with and without faculty status to study whether there was any statistical significance between librarians' experience levels, time spent at an institution, their tenure status, and how beneficial they rated tenure to be. This study showcases the ways in which one's experience with the tenure process shadows one's perception of tenure and brings to light a stark selective perception bias affecting librarians' opinions about tenure in academic libraries that seems to grow over time spent on the job.

\section{Literature Review}

Faculty status has been discussed and studied from a variety of different viewpoints and for a variety of different reasons, and there exist many articles that detail this dialog. ${ }^{6}$ In fact, as Bruce R. Kingma and Gillian M. McCombs suggest, "More has been written about this subject than about any other related topic in academic librarianship." 7 The first body formally espousing faculty status for academic librarians was the Committee on Academic Status under the University Libraries Section of the Association of College and Research Libraries (though faculty status for academic librarians had been proposed much earlier by individuals and institutions). The committee officially endorsed faculty status in $1959 .{ }^{8}$ Given the fact that discussions on faculty status span such a long period of time, the authors chose to focus on select thought pieces and research articles surrounding the debate for this literature review.

Arguments against faculty status include Blaise Cronin's famous opinion piece blasting faculty status as a time-wasting pursuit meant to boost librarians' egos. He writes: "Faculty status, whatever the feel-good factor, won't compensate for mediocre professional skills, nor materially improve the application of already honed skills." In fact, he concludes, "If anything, the obsession with status merely detracts from cus- 
tomer service and weakens the profession's public image." ${ }^{9}$ Cronin cites the studies conducted by Kingma and McCombs that point out the overwhelming opportunity costs sustained by institutions granting faculty status to its librarians.

Such dollar amounts, Kingma and McCombs report, are incurred from things like release time and repurposed time-which adds up more for academic librarians than it seems to for teaching faculty, according to their study. ${ }^{10}$ This means that, if the librarian cannot complete daily tasks warranted by the tenure process, "the tasks are absorbed by other staff members. If the librarian's task/function is not performed, the consequences for the patrons is a loss of service." 11

Another worry is that faculty status is a distraction from the "primary mission" of the library. ${ }^{12}$ Faculty status has been described as counterintuitive to the library profession given that the daily realities and responsibilities of librarians differ so much from those of faculty outside the library. ${ }^{13}$ Such differences can sometimes cloud and confuse a librarian's professional identity, as shown by new research from Shin Freedman. ${ }^{14}$ Examples of these differences included the way a librarian's time is allocated (vs. the time allocation of a faculty member outside the library) as well as contract length - giving faculty outside the library more time during the summer to complete scholarship, putting a librarian at a disadvantage when it comes to publishing. ${ }^{15}$ There are also potential differences in motivation between a service-based profession that plays a supporting role and an instruction/research-based profession that plays a leading role.

Indeed, studies have found that library faculty do publish less often than faculty outside the library; whether that is detrimental to their tenure prospects remains another issue entirely, and studies show that rates of tenure approval seem to be similar among academic librarians and their peers outside the library. ${ }^{16}$ Yet even though the publishing track in actuality may be less robust, academic librarians still feel the pressure to publish, perhaps to the detriment of their other job duties "including reference collections, or teaching." 17

Related to publishing is the conversation surrounding the uneven preparation the MLS degree affords a librarian to succeed in academia and, after graduation, the uneven institutional support in universities in terms of mentoring provided for their tenure-track librarian faculty members. ${ }^{18}$ The fact that faculty status can be given to an individual holding only a master's degree may also invite resentment from other faculty members holding PhDs, some authors have noted. ${ }^{19}$

A final concern that is treated by research studies is the number of the articles that look at social issues within the academic library related to tenure. Research indicates that there may be lifestyle ramifications of faculty status in the academic librarywith employees who are parents feeling more pressure and anxiety than employees without children, ${ }^{20}$ and female tenure-track librarians feeling higher levels of stress than males. ${ }^{21}$ Such issues are inextricably connected to faculty status and its effect on an individual's well-being.

Yet, despite the concerns, support for faculty status remains strong in the literature. One reason is the protection that tenure affords in the form of academic freedom - a reason cited by many scholars. As explained by Catherine Coker, Wyoma vanDuinkerken, and Stephen Bales, "librarians require the protections offered by tenure to continue contributing to their profession without administrative repercussions should a librarian choose to publish or teach on controversial topics." 22 Related to a protected environment is the issue of a creative environment where motivation is key to success - this is ostensibly encouraged by the tenure process. ${ }^{23}$

Other authors note that tenure helps an individual commit to a university, but it also helps a university commit to an individual by providing equitable pay, long-term employment, and incentives to stay and grow in one's position. ${ }^{24}$ It also provides 
improved "stature and recognition within the university as opposed to a staff position." ${ }^{25}$ Responding to the concern that faculty status is implemented differently at different institutions, some authors find this flexibility attractive, and actually a boon: "The realization that faculty status is not a static state and may be very different across institutions should offer ... librarians more hope in finding a particular library that offers the responsibilities and opportunities commensurate with their own skill set and attributes." 26

Though stress levels among academic librarians vary, satisfaction rates have also been empirically studied within discussions of faculty status, and it has been found that librarians with faculty status are "more satisfied with their work, more involved, and more in control of their jobs, more informed, and more connected to their institutions and to the profession." ${ }^{27}$ Such findings are corroborated by Heidi M. Vix and Kathie M. Buckman, who find a positive correlation between rank and satisfaction rates. ${ }^{28}$

Faculty status's benefit to the institution also has been studied with some authors finding that "on campuses where teaching is important, the impact of faculty status appears to be significant" in terms of its positive impact. ${ }^{29}$ This may be due to opportunities for innovation, professional development, and teaching goals as supported by tenure. ${ }^{30}$

In the end, there is significant opinion-based discussion in the literature dedicated to faculty status in the academic library, but fewer research studies available that consider how academic librarians on the whole perceive tenure and its benefits. This article attempts to make their voices a stronger part of the conversation.

\section{Methodology}

Researchers conducted a survey that asked academic librarians detailed questions regarding faculty status and tenure, some of which are reported on in this article. Deans and library HR directors of 110 ARL libraries received the e-mail survey to distribute to professional librarians in their institutions. Of these, twenty-five institutions responded. Institutions whose policies, practices, or terminologies differentiated between faculty status and tenure were asked to decide if they aligned with ALA's definitions of faculty status, tenure, or some combination of the two. An overview of faculty status/tenure in these institutions is as follows: fifteen of the twenty-five granted faculty status and tenure to their librarians, eight of the twenty-five granted librarians neither faculty status nor tenure, and two of the twenty-five granted their librarians faculty status but not tenure. Because most ARL libraries fall into one of the first two groups (offering faculty status and tenure or offering neither), the two libraries that offered faculty status but not tenure were omitted from the in-depth analysis performed in this article. The small sample size and statistically significant variation between the two schools led the authors to believe that they could not be considered representative of any larger group.

Respondents were first asked a series of identification questions to help gain a sense of the demographics at play. These questions included rank, whether the respondent had achieved tenure (if applicable), and how long the individual had worked at his or her current institution. After this was a series of questions on faculty status. These questions were broken up into two types: agreement statements and value statements (see appendix A).

Respondents were recorded on a Likert scale of $1-7$, with 7 representing strong agreement or perceived value. Because survey questions were based on the individual librarian's personal perception and experience with faculty status, personal pronouns were used when applicable. For those librarians in institutions without faculty status, personal pronouns were replaced with "librarians" (see Appendix A). 
A total of 846 librarians responded to the survey. A breakdown of librarians with and without faculty status is as follows: from the 846 total respondents, 527 respondents were from faculty institutions offering faculty status and tenure, 254 were from nonfaculty institutions offering neither faculty status nor tenure, and 65 were from libraries that offered faculty status but not tenure. As explained above, this final group of 65 was excluded from the analysis, meaning that researchers use the terms "faculty status" and "tenure" interchangeably in the discussion of the results, since any institution offering faculty status in the findings also offered tenure. Of the institutions analyzed that offered tenure, two were private institutions and thirteen were public institutions. Of the non-tenure-granting institutions, three were private and five were public.

Responses to questions were initially analyzed using a two-factor analysis of variance, including a test for the interaction effect $(\alpha=.05)$. One of the factors considered was the two main groups - librarians at institutions offering faculty status and tenure to librarians, and librarians at institutions offering neither faculty status nor tenure to librarians. The second factor was the experience level, meaning length of time at the current institution of the respondent, divided into two levels: more than six years (the time it generally takes to achieve tenure) and fewer than six years. The authors found that the interaction between the groups was significant for every question analyzed, so two-tailed two-sample t-tests were used to compare means between the four different groups. T-tests were chosen since it is safe to assume interval data as participants were asked to respond based on a 1-7 scale and the data have similar variances within groups. Furthermore, for each question analyzed, researchers report robust sample sizes. Analyzing responses between librarians at institutions offering faculty status and tenure and those at institutions offering neither faculty status nor tenure, whose time in the workplace was similar, rendered telling differences in perceptions of tenure.

\begin{tabular}{|l|c|c|c|c|c|}
\hline \multicolumn{7}{|c|}{$\begin{array}{c}\text { TABLE 1 } \\
\text { Sample Sizes }\end{array}$} \\
\hline Question & 1 & 2 & 3 & 4 & 5 \\
\hline Tenured & 288 & 290 & 285 & 280 & 281 \\
\hline Tenure-Track & 166 & 165 & 159 & 158 & 158 \\
\hline Nonfaculty $\geq 6$ & 156 & 155 & 148 & 150 & 150 \\
\hline Nonfaculty $<6$ & 91 & 90 & 83 & 82 & 82 \\
\hline Totals & 701 & 700 & 675 & 670 & 671 \\
\hline
\end{tabular}

\section{Findings}

In this article, four different sample groups are compared: tenured librarians with more than six years of experience, non-faculty-status librarians with more than six years of experience, tenure-track librarians with fewer than six years of experience, and non-tenure-track librarians with fewer than six years of experience. The authors wanted to compare differing perceptions of tenure against the amount of time spent working in one's institution and against one's experience with the tenure process.

When responding to the value statement "faculty is ultimately beneficial, directly or indirectly, to library patrons," the results of the analysis indicate that there was an interaction between the different groups and their experience levels. The results of this question are illustrated in figure 1. 


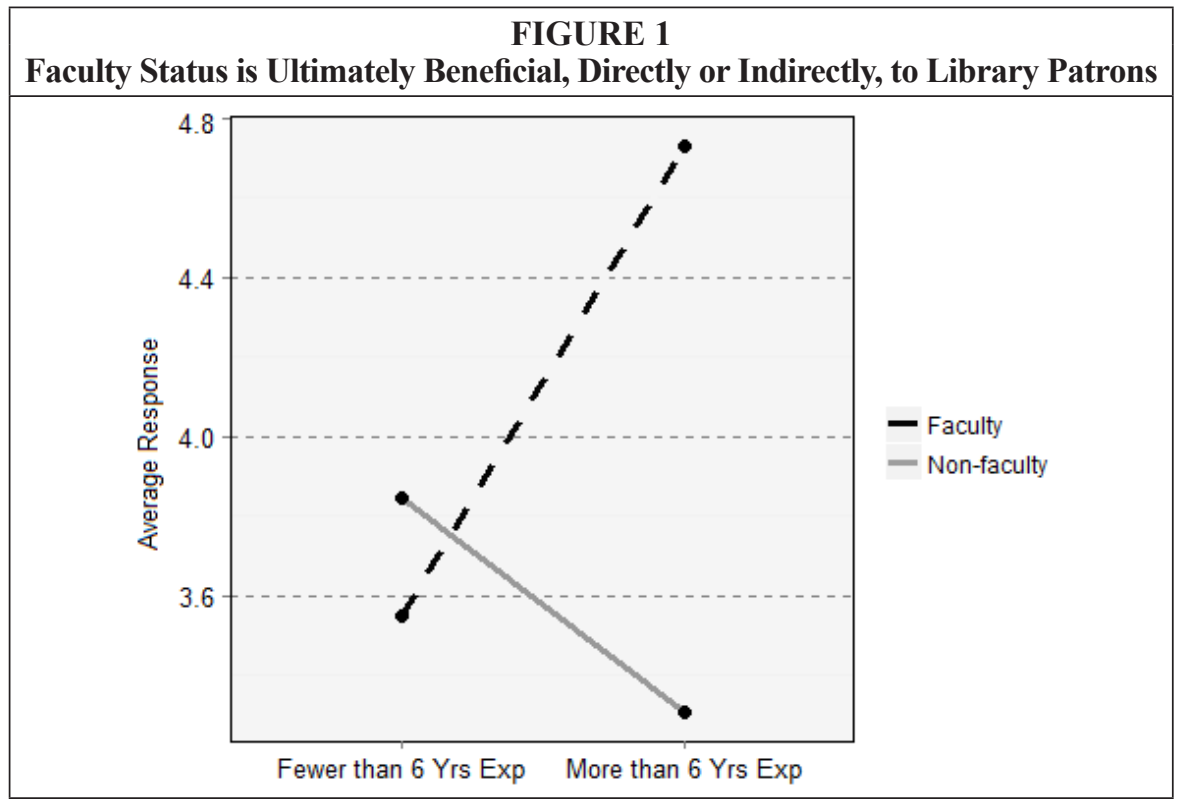

The points on the graph represent the sample means in each of the four distinct subgroups. Those who had been granted tenure reported statistically significant higher scores (suggesting they rated tenure as more beneficial) when compared to both their colleagues on the tenure track and those with similar levels of experience at nonfaculty institutions. There is an opposite trend for the two groups with less experience. Those at non-tenure institutions with fewer than six years of experience rated the benefit of tenure to the patron as higher than did those librarians undergoing the tenure process. Other questions asked had similar results.

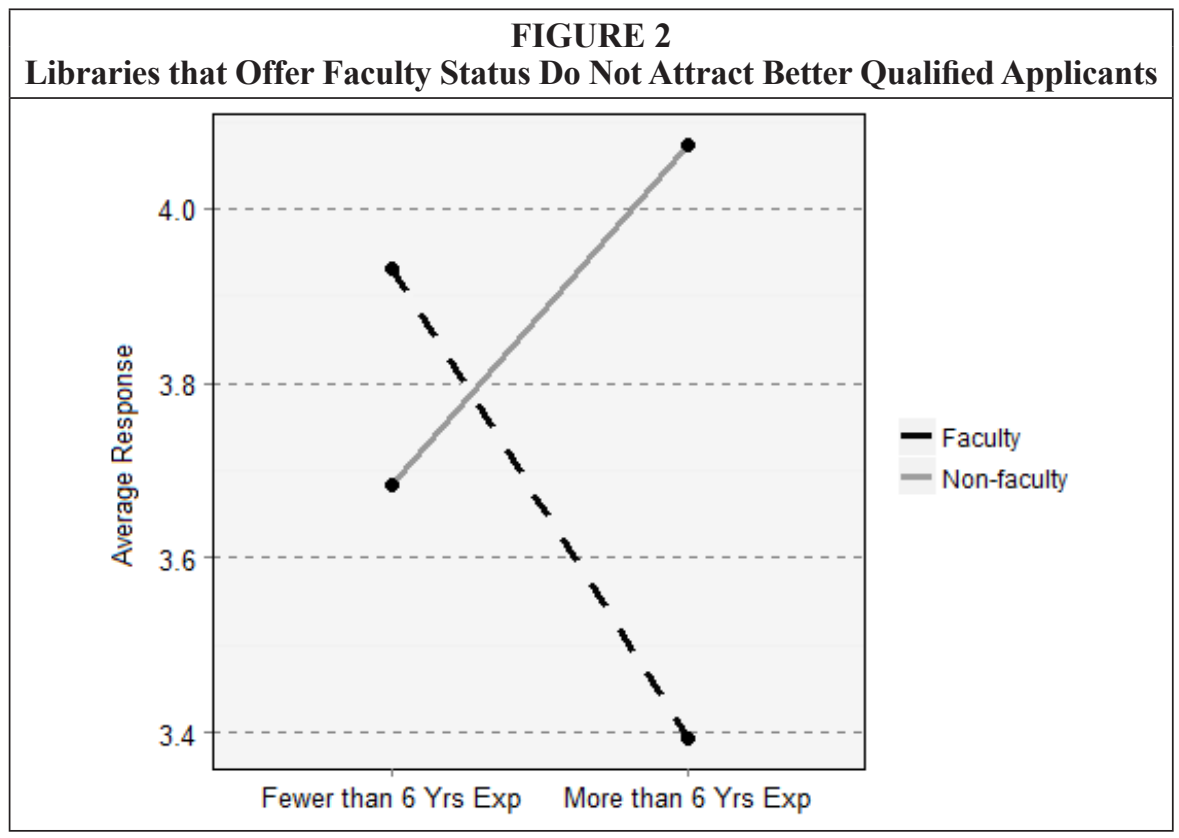


Figure 2 shows the results for the agreement statement, "libraries that offer faculty status do not attract better qualified applicants." Because the statement was a negative one (do not attract), the results show nonfaculty with six years of experience or more agreeing at higher levels than their tenured counterparts, and those with fewer than six years of experience disagreeing more than their tenure-track counterparts.

Figure 3 reports the results to the agreement statement "faculty status is an important factor in retaining employees." Retained employees may be assumed to be more knowledgeable, better trained, and more familiar with needs of patron types particular to their institutions. The results of this question are similar to the above two examples, with tenured librarians agreeing with the question more than those on tenure track, and non-tenure-track librarians with fewer than six years of experience agreeing much more than non-tenure-track librarians with more than six years at their institutions.

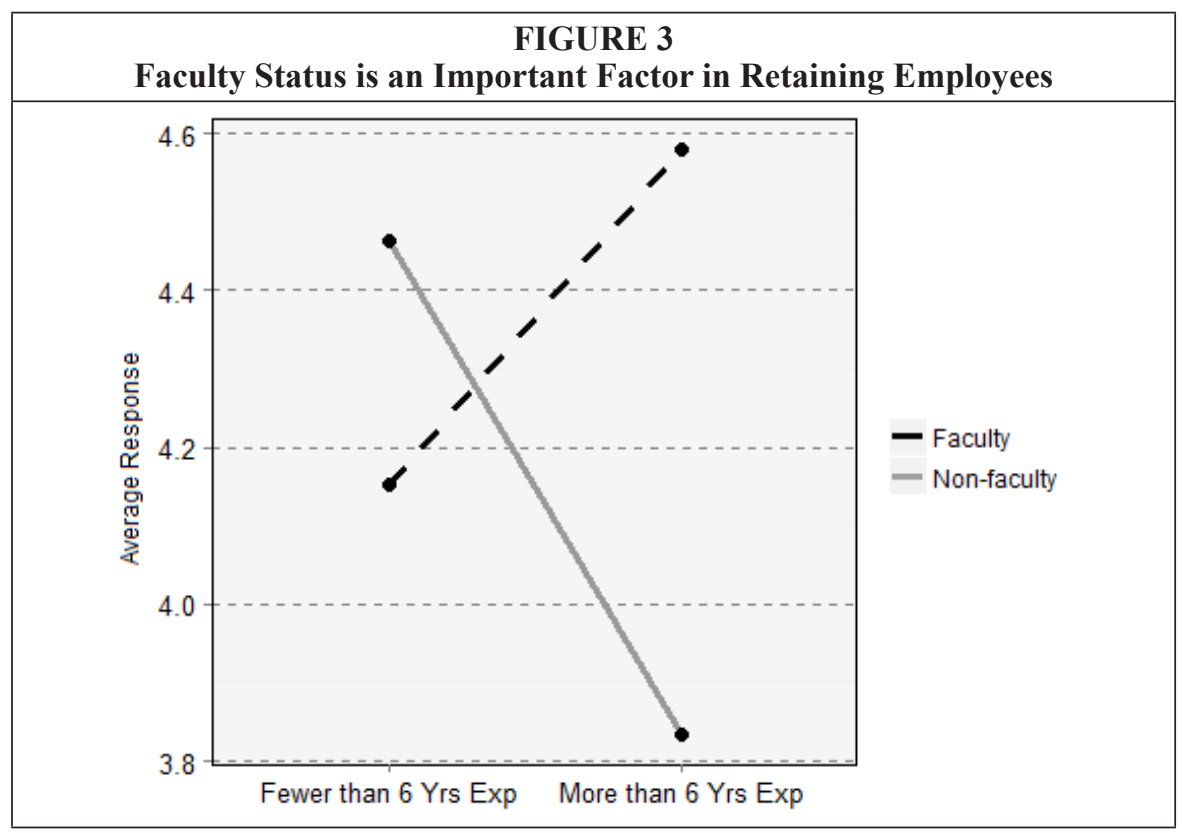

In figure 4, librarians with faculty status were asked to rate the value statement "faculty status motivates me to give extra effort in my job," while those at nonfaculty institutions were asked to rate a similar statement: "faculty status motivates librarians to give extra effort in their jobs." It is assumed that giving effort in one's job is an indication of quality work that benefits patrons and institutions.

This figure shows that those who had been granted tenure reported statistically significant higher scores when compared to both their colleagues on the tenure track, and those with similar levels of experience at nonfaculty institutions. Those who were on the tenure track reported similar scores to nonfaculty with fewer than six years of experience. Nonfaculty with six or more years of experience had statistically significant lower scores than nonfaculty with less experience and those who had achieved tenure (see tables 2-3).

When breaking down the extent to which those with more experience (six years or more) agree with this statement, it shows that relatively large percentages of these groups rate the question either a 1-disagree strongly or 7-agree strongly. Nearly a third $(28.28 \%)$ of tenured librarians strongly agreed that faculty status motivated them 

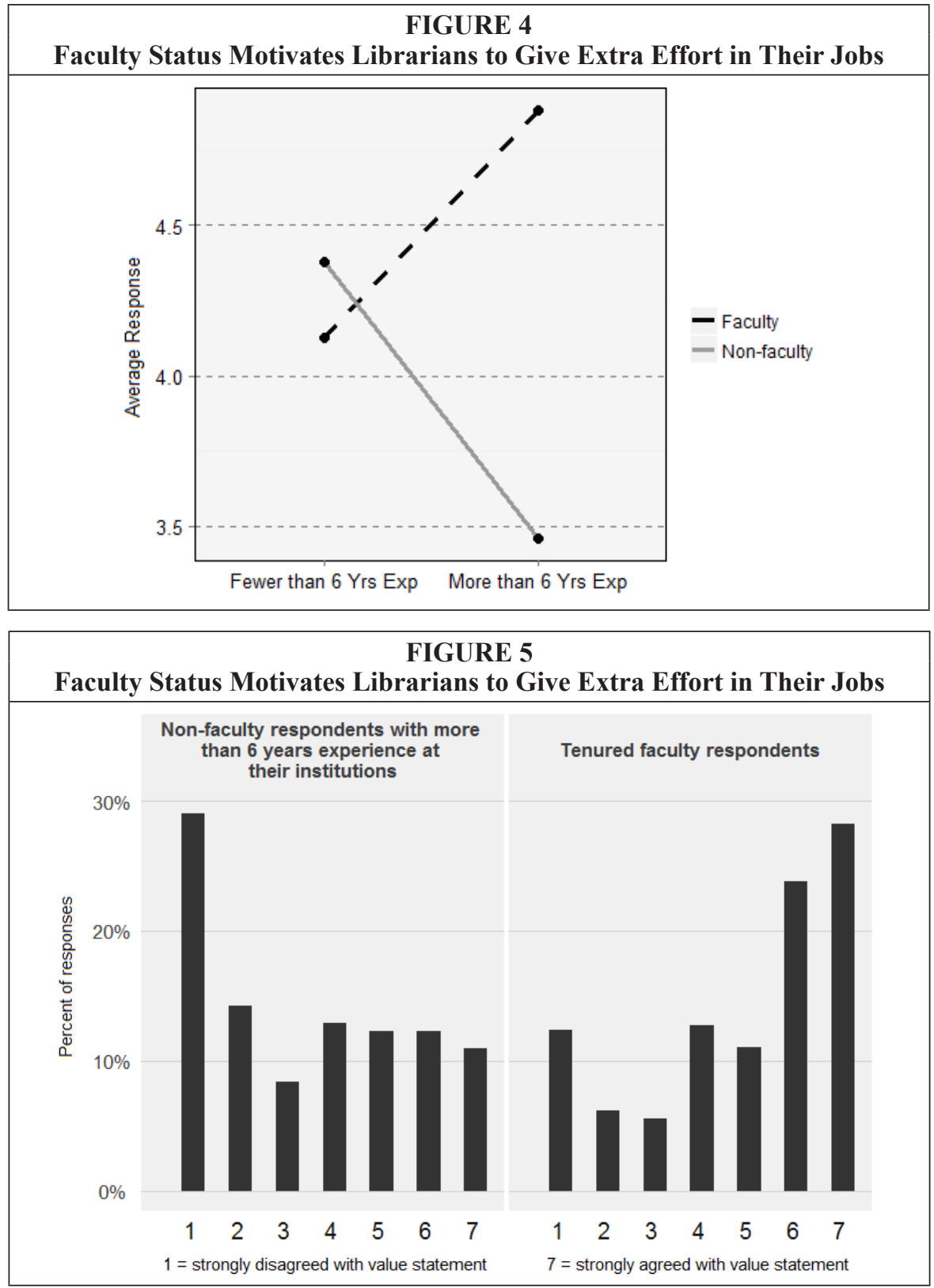

to give extra effort in their jobs, while $29.03 \%$ of nonfaculty with more than six years of experience strongly disagreed that faculty status motivates librarians to give extra effort in their jobs (see figure 5).

\section{Discussion}

Analyzing these data begs many questions about the significant divide in professional attitudes toward tenure's benefits - a divide that is seemingly contradictory in that it inverts throughout time. On the one hand, those who have achieved tenure see the 


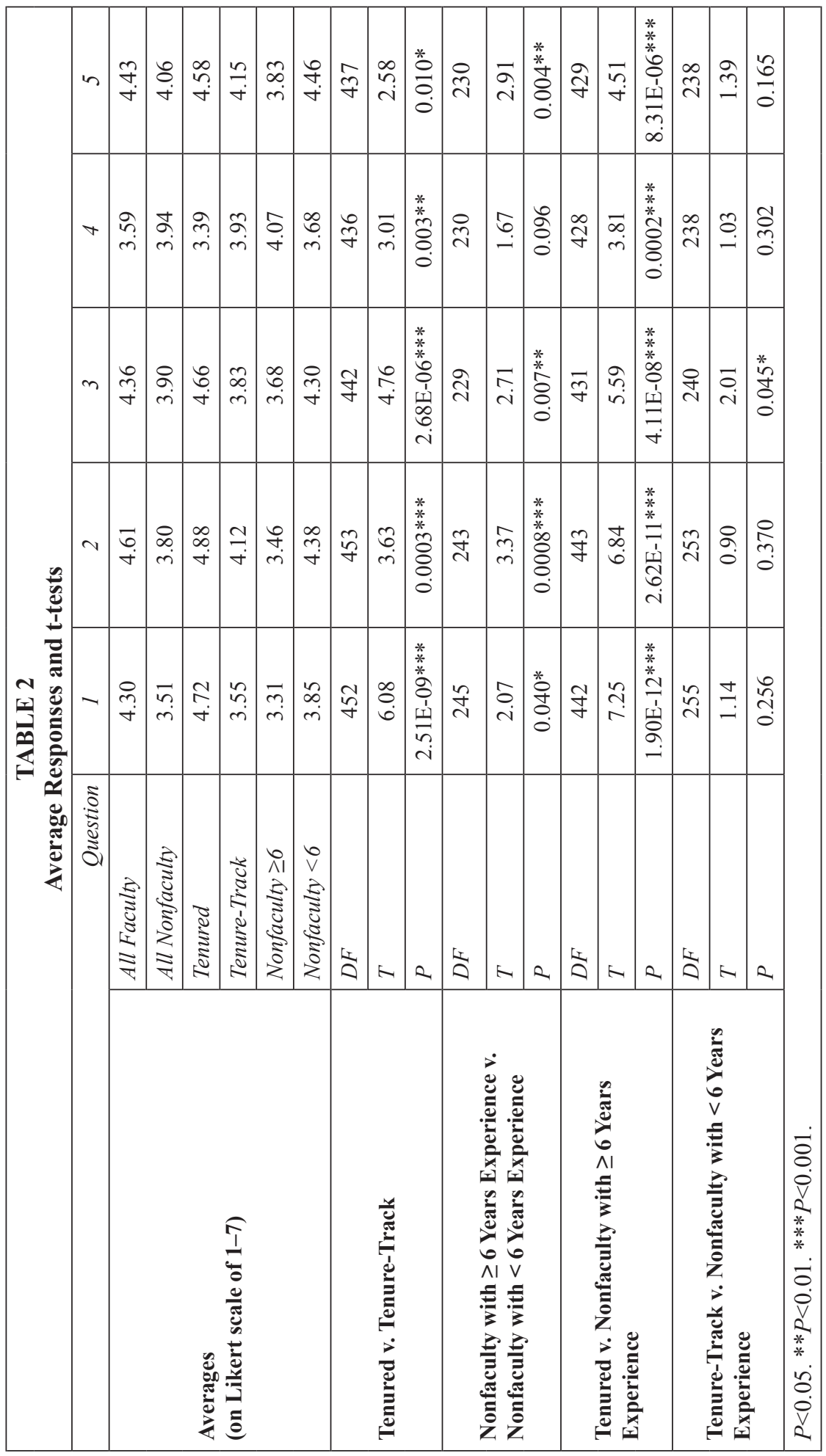




\begin{tabular}{|l|c|c|c|c|c|}
\hline \multicolumn{7}{|c|}{ ANOBLE 3 } \\
\hline Question 1 & DF & Sum of Squares & Mean Square & F value & P value \\
\hline Group & 1 & 100.16 & 100.16 & 25.41 & $5.90 \mathrm{E}-07$ \\
\hline Experience & 1 & 53.61 & 53.61 & 13.6 & 0.0002 \\
\hline Interaction & 1 & 109.92 & 109.92 & 27.89 & $1.72 \mathrm{E}-07$ \\
\hline Residuals & 697 & $2,747.07$ & 3.94 & & \\
\hline Question 2 & DF & Sum of Squares & Mean Square & Fvalue & Pvalue \\
\hline Group & 1 & 105.23 & 105.23 & 23.72 & $1.38 \mathrm{E}-06$ \\
\hline Experience & 1 & 4.52 & 4.52 & 1.02 & 0.313 \\
\hline Interaction & 1 & 103.66 & 103.66 & 23.36 & $1.65 \mathrm{E}-06$ \\
\hline Residuals & 696 & $3,087.97$ & 4.44 & & \\
\hline Question 3 & DF & Sum of Squares & Mean Square & Fvalue & Pvalue \\
\hline Group & 1 & 32.46 & 32.46 & 10.78 & 0.0011 \\
\hline Experience & 1 & 17.01 & 17.01 & 5.65 & 0.018 \\
\hline Interaction & 1 & 74.01 & 74.01 & 24.58 & $9.03 \mathrm{E}-07$ \\
\hline Residuals & 671 & $2,020.3$ & 3.011 & & \\
\hline Question 4 & DF & Sum of Squares & Mean Square & Fvalue & P value \\
\hline Group & 1 & 18.43 & 18.43 & 5.94 & 0.015 \\
\hline Experience & 1 & 7.33 & 7.33 & 2.36 & 0.125 \\
\hline Interaction & 1 & 29.94 & 29.94 & 9.65 & 0.002 \\
\hline Residuals & 666 & $2,066.97$ & 3.10 & & \\
\hline Question 5 & DF & Sum of Squares & Mean Square & F value & P value \\
\hline Group & 1 & 20.77 & 20.77 & 7.73 & 0.006 \\
\hline Experience & 1 & 0.64 & 0.64 & 0.24 & 0.627 \\
\hline Interaction & 1 & 38.95 & 38.95 & 14.50 & 0.0002 \\
\hline Residuals & 697 & $1,792.03$ & 2.69 & & \\
\hline
\end{tabular}

benefit to faculty status. Contrastingly, those in the tenure process (working for fewer than six years in the library) reported that tenure was generally less important to them than for either their tenured colleagues or their non-tenure-track peers who had worked in a library setting for a similar amount of time. What the study indubitably highlights is a selective perception bias that grows over time. Though at the beginning of a librarian's career there is a small difference between perceived benefit of tenure (with those not on the tenure track rating it as more beneficial than those on tenure track), after six years, the disparity between those with tenure (who rate its benefit as high) and those not working at tenure-granting institutions (rating its benefit as low) is significantly larger.

Why does finally achieving tenure so drastically change one's perception of its benefit? Does maturation into a professional (which takes time) change one's perception? If so, after years of experience it seems as if respondents are more likely to rate their own experience (be it tenure or nontenure) as more valuable. Is this an issue of self- 
aggrandizement or is the benefit of faculty status in the eye of the beholder, which in the case of more experienced librarians, behold themselves as the standard? Indeed, Shalu Gillum reports that the argument "good librarians would be just as good without [faculty status]" could be used as an argument in favor of faculty status or against it. In other words, if a librarian thinks he or she is a good librarian with tenure, that librarian may think that tenure made him or her a good librarian. Or, if, after several years' worth of experience without the tenure process, the librarian would think he or she is a good enough librarian without it. ${ }^{31}$

In contrast, for those with fewer years of experience or those undergoing the tenure process, does the stress of the tenure process affect one's vision-or the perceived benefit-of one's faculty status? Why do non-tenure-track librarians who have worked for a shorter number of years see faculty status as more beneficial than those who are actually working on achieving tenure? Why does this group also rate it as more beneficial than non-tenure-track librarians who have worked in their institutions for more than six years? Is it an observation of their own productivity and usefulness as librarians, or something less-experienced, non-tenure-track librarians observe in those they know who are on the tenure track? Might it represent an ideal associated with tenure-track positions that then dissipates when more years of library service are under their belts?

Though these questions require further research, one thing is certain: according to the data, the two things that affect a librarian's view of tenure are the time spent on the job and whether or not the librarian in question is on the tenure track/tenured. For those librarians at institutions with faculty status, they are more likely to value tenure's benefit to patrons higher if they have more years of experience (and tenure). For those at institutions without faculty status, they are more likely to value tenure's benefit if they have fewer years of experience. This flip-flopping of opinions throughout one's career as a librarian underlines the importance of more research into the cause of such attitudes, because perceptions that librarians have of their professionalization affect not only the library and librarian greatly, but also the patron.

\section{Limitations and Further Research}

This study does not quantifiably rate the benefit of faculty status on the library patron, how it affects the actual effort given on the job, or if faculty status does or does not affect the quality of or retention of employees. This would need to be the subject of future studies whose results may have serious implications for the institution of tenure in academic libraries. Other studies might seek to assess where perception of faculty status comes from - whether these be inherited beliefs, beliefs that arise from experience, or some combination of the two. Because this study does not quantifiably rate tenure's benefit but instead seeks to understand the librarian's perception of tenure, it might also be helpful to compare the perceptions of tenure and the ways in which those perceptions influence reality across different institutions and across different faculty status models.

Adding to this limitation is the issue of visually representing the data the authors chose to discuss here, along with how respondents were grouped. Since the respondents answered the question of how long they had been working at their respective institutions by year, the data were more spread than if lumped into four distinct groups. Authors chose to visually represent the data in the line graphs with the four distinct groups and compare them because it made sense for their purposes to compare groups with vs. without tenure-track positions and those with fewer years of experience vs. those with more. Furthermore, since the data were consistent over several different question types, these comparisons were warranted. 


\section{Conclusion}

Despite any limitations, researchers feel confident that there are some important lessons for librarians, administrators, and academic institutions from this study. Given their large differences in opinions, institutions might open discussions about how tenure is perceived at their institution and try to identify from where these perceptions come. Understanding the genesis of these viewpoints will help assess what the concrete pros and cons of tenure are in the academic library. Furthermore, opening discussions might also moderate the extent to which opinions about faculty status differ by allowing individuals to express their opinions, thereby proactively encouraging librarians to see each other's points of view. It may also be helpful to break down the benefit of tenure in the short term (that is to say, while the librarian is undergoing the process) vs. the long term (after the librarian has secured tenure). The effect of tenure might, in fact, be very different at these different points in a librarian's career-in which case tenure processes and requirements could be revised.

Additionally, administrators at institutions granting tenure might assess employees' feelings during the tenure process (or lack thereof) and how that affects their views of tenure. This might include honest yearly evaluations that ask librarians to rate their own performance and job satisfaction rates - such evaluations might be anonymous, or only distributed to those who hold tenure (since those undergoing the tenure process may fear retribution for "honest" appraisal). These discussions could include assessments of stress, work/life balance, and how gratifying one's profession really is on the tenure track. Nuanced conversations regarding retention and recruitment rates and how an institution's particular tenure system affects those rates depending on the perceptions of their employees could follow such assessments. Included in these discussions might be an evaluation of what the institution considers a quality employee and what values they seek in librarians. This might change from institution to institution depending on patron needs. It might also lead to an assessment of current employees and if such employees feel that faculty status for their librarians is of benefit to their patron communities. Such assessments might also happen at institutions that do not grant faculty status to their librarians as they decide whether faculty status would benefit their patron communities.

Furthermore, at institutions that do not grant faculty status or tenure to their librarians, administrators might focus on professional development opportunities and scholarship incentives for their librarians-especially focusing on the new hires who may view tenure as beneficial. Having opportunities to expand repertoires and participate in academic discussions may help with retention and job satisfaction and address the perception among new librarians that faculty status makes for better employees.

Finally, librarians should try to analyze where their own opinions of tenure (whether they are tenure track or not) come from - and whether such perceptions are accurate. Doing this will allow individuals to become more self-reflective of their own position within the academic library, their services to patron communities, and their ability to reach their set professional goals. Overall, the implications of this study suggest that, although views on tenure vary widely, they are certainly biased by an individual's experience with tenure, as well as how many years of experience that individual has. By disentangling different factors from the question of tenure, individuals may look back on their own time spent in the workplace more critically and help become part of productive discussions that pinpoint service to patrons and how best to stay relevant both within the academy and within the rapidly changing world of the research library at large. 


\section{APPENDIX A. Sample Survey Directions and Questions}

Note: The questions below have been assigned numbers for the purposes in this article but were not assigned numbers or letters in the original survey. The questions below represent only the questions reported on in this article and do not include the entirety of the survey, which was an extensive study on faculty status in academic libraries. Capital letters and bolding below remain true to what a respondent would have seen in the original survey.

\begin{tabular}{l} 
Value Statements \\
The purpose of this section is to determine how much YOU PERSONALLY VALUE \\
certain aspects of your faculty status. Answer based on how much you personally value \\
the indicated aspect of faculty status. \\
Rank the following statements from 1 to 7,1 meaning the statement does not describe \\
your feelings at all and 7 meaning that you strongly agree that the statement describes \\
your feelings. \\
\hline Question 1: Faculty status is ultimately beneficial, directly or indirectly, to library patrons \\
\hline Question 2 (faculty version): Faculty Status motivates me to give extra effort in my job \\
\hline $\begin{array}{l}\text { Question } 2 \text { (nonfaculty version): Faculty status motivates librarians to give extra effort in } \\
\text { their jobs }\end{array}$ \\
\hline
\end{tabular}

Agreement Statements

Rate the following statements according to how much you agree that the statement reflects the PROFESSION AS A WHOLE among academic libraries. Do not answer based on whether or not you personally value the concept addressed in each statement.

Rank the following statements from 1 to 7, 1 meaning you STRONGLY DO NOT AGREE with the statement at all and 7 meaning that you STRONGLY AGREE with the statement.

Question 3: Faculty status is ultimately beneficial, directly or indirectly, to library patrons

Question 4: Libraries that offer faculty status do not attract better qualified applicants

Question 5: Faulty status is an important factor in retaining employees

\section{Notes}

1. "Association of College and Research Libraries Standards for Faculty Status for Academic Librarians," ACRL, October 2011, available online at www.ala.org/acrl/standards/standardsfaculty [accessed 12 August 2015].

2. Paul Alan Wyss, "Library School Faculty Member Perceptions Regarding Faculty Status for Academic Librarians," College \& Research Libraries 70, no. 4 (July 2010): 384-85.

3. Ibid.

4. Mary K. Bolin, "Librarian Status at U.S. Research Universities: Extending the Typology," Journal of Academic Librarianship 34, no. 5 (Aug. 2008): 417.

5. Rachel Applegate, "Deconstructing Faculty Status: Research and Assumptions," Journal of Academic Librarianship 19, no. 3 (1993): 158; Jacalyn E. Bryan, "The Question of Faculty Status for Academic Librarians," Library Review 56, no. 9 (2007): 781. Both authors discuss the lack of empirical evidence in conversations surrounding faculty status in academic libraries. 
6. For examples of such articles, see Emily Werrell and Laura Sullivan, "Faculty Status for Academic Librarians: A Review of the Literature," College \& Research Libraries 48 (1987): 98-103; Nathan Hosburgh, "Librarian Faculty Status: What Does It Mean in Academia?" Library Philosophy and Practice (June 2011): 31-37; Shalu Gillum, "The True Benefit of Status for Academic Reference Librarians," Reference Librarian 51, no. 4 (2010): 322; Catherin Coker, Wyoma vanDuinkerken, and Stephen Bales, "Seeking Full Citizenship: A Defense of Tenure Faculty Status for Librarians," College \& Research Libraries 72, no. 1 (2011): 406-20; Jacalyn E. Bryan, "The Question of Faculty Status for Academic Librarians," Library Review 56, no. 9 (2007): 781-87.

7. Bruce R. Kingma and Gillian M. McCombs, "The Opportunity Costs of Faculty Status for Academic Librarians," College \& Research Libraries 56, no. 3 (1995): 258.

8. Faculty Status for Academic Librarians: A History and Policy Statements (Chicago: ALA, 1975), v.

9. Blaise Cronin, "The Mother of All Myths," Library Journal 126, no. 3 (Feb. 2001): 144.

10. Kingma and McCombs, "The Opportunity," College \& Research Libraries, 260.

11. Ibid, 259.

12. Janet Swan Hill, "Constant Vigilance, Babelfish, and Foot Surgery: Perspectives on Faculty Status and Tenure for Academic Librarians," portal: Libraries and the Academy 5, no. 1 (2005): 8.

13. Paul Alan Wyss, "Library School Faculty Member Perceptions Regarding Faculty Status for Academic Librarians," College \& Research Libraries 71, no. 4 (2010): 385.

14. Shin Freedman, "Faculty Status, Tenure, and Professional Identity: A Pilot Study of Academic Librarians in New England," portal: Libraries and the Academy 14, no. 4 (2014): 555.

15Julie J. McGowan and Elizabeth H. Dow, "Faculty Status and Academic Librarianship: Transformation to a Clinical Model," Journal of Academic Librarianship 21, no. 5 (1995): 346.

16. W. Bede Mitchell and Mary Reichel, "Publish or Perish: A Dilemma for Academic Librarians?" College \& Research Libraries 60, no. 3 (1999): 240.

17. Corey M. Johnson and Elizabeth Blakesley Lindsay, "Why We Do What We Do: Exploring Priorities within Public Services Librarianship," portal: Libraries and the Academy 6, no. 3 (2006): 363.

18. Amy J. Vilz and Molly Dahl Poremski, "Perceptions of Support Systems for Tenure-Track Librarians," College \& Undergraduate Libraries 22, no. 2 (2015): 150.

19. Danielle Bodrero Hoggan, "Faculty Status for Librarians in Higher Education," 3, no. 3 (2003): 436.

20. Ibid, 438.

21. Quinn Galbraith, Leanna Fry, and Melissa Garrison, "The Impact of Faculty Status and Gender on Employee Well-being in Academic Libraries," College \& Research Libraries (2015): 71.

22. Coker, vanDuinkerken, and Bales, "Seeking Full Citizenship," 417.

23. Gillum, "The True Benefit," 327.

24. Jeanie M. Welch and Frada L. Mozenter, "Loosening the Ties That Bind: Academic Librarians and Tenure," College \& Research Libraries 67, no. 2 (2006): 173.

25. Hosburgh, "Librarian Faculty Status," 34.

26. Ibid, 32 .

27. Corey M. Johnson and Elizabeth Blakesley Lindsay, “Why We Do What We Do," 348.

28. Bonnie Horenstein, "Job Satisfaction of Academic Librarians: An Examination of the Relationships between Satisfaction, Faculty Status, and Participation," College and Research Libraries 54 (1993): 260, 264.

29. Richard W. Meyer, "A Measure of the Impact of Tenure," College \& Research Libraries 60, no. 2 (1999): 118.

30. Hoggan, "Faculty Status for Librarians," 433-435.

31. Gillum, "The True Benefit," 322. 